\title{
Beyond solidarity, reciprocity and altruism: moral capital as a unifying concept in intergenerational support for older people
}

\author{
MERRIL SILVERSTEIN*, STEPHEN J. CONROY† \\ and DAPHNA GANS:
}

\begin{abstract}
The purpose of this article is to review, contrast and synthesise several major intellectual streams that have guided theoretical development and empirical research in the area of intergenerational family support to older people: (a) normativeintegrative approaches that focus on cohesion between family members based on bonds of solidarity and norms of filial obligation, and (b) transactional approaches that are primarily concerned with identifying motives for resource transfers across generational lines. We propose the concept of moral capital-defined as the stock of internalised social norms that obligate children to care for and support their older parents-the transmission of which lies at the intersection of self-interest (for parents) and altruism (for children). Using data from a multigenerational family study, we present an empirical analysis showing that a strong positive correspondence in the filial obligations of adult children and their older mothers - arguably the result of intergenerational transmission-elevated the supportive behaviour of children. We suggest that moral capital may be a useful unifying concept that bridges disciplinary and theoretical divides in the study of intergenerational transfers to elderly people by helping resolve the paradox of how self-interest and selflessness can co-exist within families.
\end{abstract}

KEY WORDS-ageing families, intergenerational relations, social support, solidarity, altruism, transfers, moral capital.

\section{Introduction}

The purpose of this paper is to review, contrast and integrate several of the major intellectual streams that have guided theoretical development and empirical research in the area of intergenerational family support to older

* Davis School of Gerontology, University of Southern California, Los Angeles, USA.

$\dagger$ School of Business Administration, University of San Diego, California, USA.

+ Center for Health Policy Research, University of California at Los Angeles, USA. 
people. These streams can roughly be divided into those that emphasise bonds of solidarity and integration (as well as conflict), and those that emphasise transactions between family members (usually in the form of time and money transfers). While not necessarily contradictory, these two traditions evolved out of different sets of assumptions about the nature of adult intergenerational bonds and the principles under which they operate. As one of the most durable bonds in the family, adult parent-child relationships have received intense scrutiny in the social and behavioural sciences, yet models on which research are based have evolved along divergent paths. In the first section of this article we review two theoretical streams of scholarship on the ageing family that developed concurrently with each other but are rarely intersected. The second section proposes an integrative paradigm for considering intergenerational support provision in the ageing family-based on the concept of moral capital - that borrows from each stream. The third section provides an empirical analysis demonstrating the utility of our hybrid perspective.

\section{Normative-integrative approaches to intergenerational relations}

A normative-integrative approach to intergenerational family relations focuses on cohesion between family members based on bonds of solidarity and norms of filial obligation. The roots of this approach can be seen in early tracts in family sociology. In what resembles a contemporary critique of 21 st-century society, Louis Wirth's classic commentary on America of the early 2oth century noted that the very basis of family life was being threatened by declining fertility rates and postponed marriage among the new urban inhabitants of America (Wirth 1938). He noted that 'weakening bonds of kinship' were being replaced by 'impersonal, superficial, transitory, and segmental' relationships. Wirth and his contemporaries in the Chicago school of sociology (e.g. Ogburn 1933) concluded that the growing alienation of urbanites in the teeming cities of the early 2oth century could be partially explained by the loss of family-centrality in everyday life. Invoking Durkheim's concept of solidarity as the binding force of society, these scholars were concerned with what they viewed as the unravelling social fabric of family life. While the family experiences of older adults was little considered in their critiques, the general notion was that young adults had become unmoored from older generations - to the detriment of all concerned.

\section{Functionalist-normative perspectives}

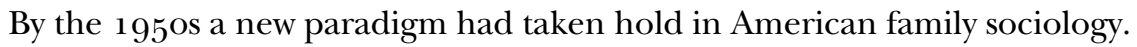
Prompted by the growth in prosperity following World War II, social theorists 


\section{Merril Silverstein et al.}

began to consider the nuclear family as the family organisation best suited to the demands of a modern economy that required skilled workers in dispersed labour markets. In this framework the unmooring of adults from their families of orientation was considered an inevitable and necessary consequence of societal modernisation (Burgess 1960; Goode 1963). In this line of reasoning, extended-familism was considered incompatible with an increasingly technocratic society that required a trained, specialised and geographically mobile labour force. Nuclear families (characterised by a strongly gendered division of work/family labour and small size) needed to be unencumbered by the older generations in order to maximise their success, and, by extension, secure the economic vitality of the nation (Parsons and Bales 1955).

In reaction to the early functionalists, later theorists, such as Litwak (1985) and others, argued that families and the formal machinery of society existed in separate spheres but necessarily intersected. They considered families as constituting a unique social organisation that stood in contrast, and sometimes in opposition, to bureaucratic formal organisations. Whereas the family membership was based on ties of emotion and commitment, bureaucratic organisations relied on specialisation, rules of operation and participation based on merit. For example, older adults could rely on formal home-care services because bureaucratic enforcement of training, credentialling, supervision and regulation insured that care was delivered with standardised quality; family members, on the other hand, could similarly deliver home care but would operate out of emotional connectedness and a sense of duty. Paying family care-givers was seen as introducing a self-interest motive into the family modus operandi that stood in contradiction to its basic incentive structure and functional imperative.

Functionalist theories of this later variety were supported by empirical research that revealed intergenerational strength in the face of social change. Although opportunities for face-to-face interaction had reduced, relatively rapid transportation and communication technologies allowed the maintenance of strong affective ties between generations - in what came to be known as intimacy-at-a-distance (Rosenmayer 1968). The modified-extended familygeographically mobile yet emotionally close - became the filial prototype that could be considered to be isomorphic with respect to the demands of modern economy; it also served as a corrective to the isolated extended family as a normative family form (Litwak 1960; Shanas and Sussman 1977).

\section{Intergenerational solidarity, conflict and ambivalence}

In the 1970s, the study of intergenerational relations turned toward codification and classification. Drawing on Durkheim's concept of social 
solidarity and Heider's (1958) and Homans' (1950) theories of smallgroup cohesion, Bengtson and colleagues began developing a 'periodic table' of the connective links between generations in the family - a model that became known as the intergenerational solidarity paradigm (Roberts, Richards and Bengtson 1991). Both a conceptual scheme and a measurement model, the solidarity paradigm itemised the sentiments, behaviours, attitudes, values and structural arrangements that bind the generations. Intergenerational solidarity was operationalised along six dimensions: affectual solidarity (emotional closeness), associational solidarity (social interaction), structural solidarity (opportunity for interaction based mostly on geographic proximity), normative solidarity (filial obligation), consensual solidarity (perceived and actual agreement on values and opinions) and functional solidarity (provisions of material, instrumental and social support). Although many studies applying the solidarity perspective have employed its range dimensions (e.g. Rossi and Rossi 1990; Silverstein, Bengtson and Lawton 1997; Whitbeck, Simons and Conger 1991), the conceptual and empirical strength of the model lay in its consideration of affective bonds between generations. Indeed, the term 'intergenerational solidarity' has come to mean emotional cohesion between generations.

Responding to criticism that the solidarity paradigm lacked coverage of negative emotions and behaviours, researchers subsequently added the dimension of conflict to the model (Clarke et al. 1999). The same period saw the rise of intergenerational ambivalence theory, a perspective that focused on the mixed positive and negative emotions that emanate from the ongoing tension between autonomy and dependence in intergenerational relationships (Leuscher and Pillemer 1998). While ambivalent feelings are obvious early in the family lifecycle, they are evident in older families as well, for example when ageing parents become dependent on their adult children (Willson, Shuey and Elder 2003). The emotional content of intergenerational relationships - both closeness and conflict - have a bearing on support patterns in ageing families (Parrott and Bengtson 1999).

\section{Transactional approaches to intergenerational relations}

In contrast to normative-integrative approaches to intergenerational relations, transactional approaches are primarily concerned with identifying motives for providing resources across generational lines. These approaches typically rely on market principles that emphasise valued transfers of time (labour) and money, typically within a reciprocity or exchange framework. The foil for this approach is the concept of altruism-defined in this 
$125^{\circ}$ Merril Silverstein et al.

scholarly camp as giving to others with the most need and the least ability to repay. We discuss these two basic orientations to intergenerational transfers.

\section{Exchange perspectives}

Reciprocity has been a consistent theme in the study of adult parent-child relationships. Adult children and their parents are considered interdependent actors who contemporaneously and dynamically exchange support to each other over the lifecourse. As achieving some level of equity in the exchange is a desired goal, this perspective maintains that the obligation to pay a debt is no less found in family relations than it is in market relations and that providers of support are at least partially motivated by self-interest.

One of the most commonly tested questions in the paradigm is that adult children who received money from their parents are the same who provide more support to them. Several investigations have shown such a pattern (Cox and Rank 1992; Lennartsson, Silverstein and Fritzell 2010; Lowenstein, Katz and Gur-Yaish 2007), but others have not or have found substantively small effects (Altonji, Hayashi and Kotlikoff 1992; Attias-Donfut 2000; McGarry and Schoeni 1997). Studies examining long-term patterns of intergenerational exchange found that parents who, in middle age, provided financial assistance to their young-adult children were more likely, in old age, to receive social support from them (Henretta et al. 1997; Silverstein et al. 2002), an affirmation of the 'support bank' hypothesis (Antonucci 1990). In a related application of exchange theory, Bernheim, Shleifer and Summers $\left(19^{8} 5\right)$ suggested that parents may strategically use the promise of a bequest to obtain assistance or attention from their children, although the evidence for this is mixed (Caputo 2002). Finally, providing support to older parents may also be intended to 'demonstrate' to offspring that elder support is an important duty of children - the eventual emulation of which behaviour may benefit the provider (Cox and Stark 1992).

\section{Altruism perspectives}

Intergenerational transfers that flow from the more affluent to the more needy are generally taken as evidence that altruistic motivations are at work (Altonji, Hayashi and Kotlikoff 1992; McGarry and Schoeni 1997). Few attempts have been made to directly measure altruism which is typically inferred from observed transfers where there is no ostensible resource benefit to the provider. Pure altruism, however, is a construct perhaps not found in nature. For instance, the terms 'tempered altruism' (Bernheim and Stark 1988) and 'constrained altruism' (Becker 1991) have been used to describe how the altruist protects himself against the depletion of resources 
and becoming the victim of exploitation. Further, scholars recognise that purely selfless acts are rare as emotional or symbolic rewards (e.g. a 'warm glow') may be derived from altruistically helping others, particularly those with whom one feels most intimate (Andreoni 1990).

Motives for intergenerational transfers are often mixed (Logan and Spitze 1995) and not easily distinguishable. Emotional and transactional elements in transfer behaviours are often inseparable. For example, transfers of time and money from parents to children tend to strengthen intergenerational attachment (Attias-Donfut 2000) and filial norms (Ikkink, Van Tilburg and Knipscheer 1999) that may lead to the appearance of reciprocal exchanges in a phenomenon known as 'double-sided' altruism (Sloan, Zhang and Wang 2002). In a rare comparative examination of this issue, Ribar and Wilhelm (2006) found evidence for both exchange and role modelling principles in the transmission of elder support attitudes across generations in Mexican-American families. In a novel challenge to the theoretical underpinnings of the demonstration effect, Jellal and Wolff (2002) contrast emulation (intergenerational continuity in supportive behaviours) and modelling (intentional effort to elicit similar behaviour in children) as explanations for upward transfers by middle-aged children in French families. The authors find stronger evidence for the former than the latter, suggesting the primacy of altruistic motivations over those of self-interest. Although parental socialisation of children to eldercare values is cited as the likely mechanism responsible for the observed cross-generational association in supportive behaviours, cultural transmission is only inferred and not directly observed.

\section{Toward a moral-economy perspective on support in ageing families}

It is clear from much of the evidence that altruism, as represented by prosocial norms, and bounded self-interest, as represented by reciprocal transfers, are important pieces of the puzzle in explaining support and care provisions by adult children for their older parents. To integrate these distinct orientations we introduce a perspective that treats the family as a moral economy. Within this perspective the concept of filial obligation as a form of moral capital that links normative and self-interest orientations because it (a) has value in shaping the behaviour of children, and (b) is transmissible from one generation to another. We begin by asking from where filial duty to older parents derives. How do parents ensure that their children will provide for them in their old age? In exploring the issue of moral capital, we address questions about the family that touch on its importance as one of the most fundamental social organisations in society. 


\section{Moral capital in ageing families}

The prescription to honour one's mother and father - found in the western Bible, the writings of Confucius and many other religious tracts - is a moral imperative found in almost all societies. However, this adage far from guarantees that adult children will actually feel responsible for assisting their ageing parents and leaves open the question of how such obligations come into being. We suggest that feelings of filial duty toward older parents is a form of moral capital that we defined elsewhere as the stock of internalised social values that obligate children to care for and support their older parents (see Silverstein and Conroy 2009). As a set of values that is transmissible from parents to children, moral capital lies at the intersection of self-interest (for parents) and altruism (for children). Putting 'normative' and 'transactional' approaches together provides leverage for better understanding how moral capital is accumulated and then redeemed in family contexts.

In carving out intellectual space for the concept of moral capital, it is useful to distinguish it from social capital. Social capital can be roughly defined as the benefits that accrue from investing in social relationships that build in others the obligation to reciprocate in order to continue (the hopefully rewarding) relationship (Coleman 1988), a phenomenon observed in social as well as family networks (Furstenberg and Kaplan 2004). What compels individuals in whom social capital is invested to fulfil their duty toward the original investors? We suggest that a normative form of social regulation specific to the type of relationship and social institution in question - that we label moral capital - is the valued good in question (In small-group applications, the concept of the moral economy can be traced to the work of Mauss $(1923 / 1967)$, who stressed moral obligations over pecuniary motives for the exchange of resources in simple societies.) When applied to intergenerational families in later life, moral capital resides in adult children as an obligation to provide assistance for their older parents. Being a 'good' (i.e. attentive, responsible) parent early on builds a reserve of goodwill in children, but gratitude may not be enough to guarantee that support from one's adult children will be forthcoming; it may also take a moral commitment on the part of children to fulfil their end of the bargain (Stein et al. 1998). Alternatively, a 'bad' parent who invests little social (or economic) capital in offspring may rely solely on his or her ability to socialise children to values of filial duty in order to ensure intergenerational support (Silverstein et al. 2002). In some sense, moral capital embodies the value of values - the certainty with which one can anticipate that others hold particular values from which they anticipate a benefit. 


\section{The transmission of moral capital}

We take as a central premise of the moral-economy approach that the transmission of familistic norms from parents to children increases the probability that parents will be able to count on their children for needed support in the future. The generalised expectation that children are obligated to support their ageing parents in times of need (Cicirelli 1993) is essentially an insurance function of children. Since there are few formal sanctions imposed on children who renege on the informal contract with parents, enforcement must rely on internalised norms of appropriate behaviour that operate in the service of reducing the risk of moral hazard - that is, of having expectations for solicitous children that do not materialise.

Little attention has been paid to the intergenerational transmission of values that inculcates in children the responsibility to respond to the needs of ageing parents. Becker (1991) came to the conclusion that such training was an inefficient strategy on the part of parents compared to leveraging resources to compel children to provide help. Yet Becker's conclusion is at odds with scholarship showing that the intergenerational reproduction of social values and ideologies is one of the chief goals of the family (Bengtson, Biblarz and Roberts 2002; Glass, Bengtson and Dunham 1986; Taris and Semin 1997). We consider the socialisation of children to familistic values to be an investment in their moral capital, much like the investment in education represents an investment in human capital. Parents often teach their children about values when they are young both by example and by discussing with them the merits of particular orientations. Children can also acquire moral capital through social interaction with peers, values-based school curricula and religious participation over which parents have some degree of control.

Any immediate 'leverage' wielded by parents to control the actions of children (as is suggested in the case of bequests) may be more important to obligations based on an altruism norm that has a long-time horizon within intergenerational families. Such norms are products of collective or subgroup belief systems, but are manifest at the individual level in terms of the felt obligation to provide support in a particular relationship under particular circumstances. The question of why a child would act against his or her own self-interest and perform altruistic acts revisits a well-known dilemma in economic theory. Adam Smith, in his 'Wealth of Nations' (1790), described how the general good is served by agents acting in their own self-interest. To the extent that an intergenerational 'family game' resembles a multi-period game with an unknown horizon, we may expect co-operative exchange to emerge as an optimal strategy - even with agents acting in their own selfish best interest. However, these 'games' may still have 


\section{Merril Silverstein et al.}

a 'final period problem' in which adult children, no matter how cooperatively they have 'played' throughout their life, are still faced with an optimal strategy to defect on their ageing parents in the end. We do not need to appeal to irrationality arguments as there are two basic explanations for acting unselfishly and assisting ageing parents: (a) they are selfish but face a credible threat from their parents to be removed from the will, or (b) they are unselfish because they receive a 'warm glow' of satisfaction from assisting their parents (Andreoni 1990). This 'warm glow' could be directly proportional to the stock of moral capital and could also be moderated by emotional attachment to the parents.

The moral capital perspective unlike those that rely on exchange and emotional solidarity implies that the child cares even when the relationship is/has been strained and there has been no initial investment or promise of an investment to stimulate a quid pro quo. It is also important to note that we refer to a depreciation of value in moral capital over time in distinct contrast to Kohlberg's (1981) stage theory of moral development that refers only to a monotonic increase in values over time. Given that social and moral capital in families may lay dormant for many decades, it is possible that the value of parental investments will depreciate over time due to memory lapses or be remembered differently by parent and child, raising the possibility that the child as an adult may renege on the implicit contract to reciprocate. The potential for uncertainty in what is essentially an extra-legal contract demands that motivation be reinforced by internalised commitments or a sense of duty on the part of the adult child.

Becker formalised this discussion in his Nobel lecture $(1993,400)$ and suggested that parents may attempt to instill 'guilt, obligation, duty, and filial love that effectively, can "commit" children to helping them out (in old age).' He goes on to suggest that 'social sanctions' may compel children to uphold their end of the bargain, particularly if they consider reneging on the implicit intergenerational contract (Becker 1991).

However, this is not say that the transmission of normative obligation from parents to children is always complete and, if complete, always enforceable. Even children who embrace filial responsibility as a desired goal do not necessarily plan to, or actually provide support to their parents (Peek et al. 1998). Normative obligations as ideals are differentially expressed depending on the resources, constraints and alternative obligations of the provider, and the level of need of the recipient (Finch and Mason 1991). Parents also place their bets on some children more than others in terms of who is more likely to absorb and retain the normative training as a strategic decision, in a sense 'grooming' the future care-giver. Filial commitment - moral capital in our designation - may vary across siblings and adult children may make decisions about caring for an aged parent 
partially based on their anticipation that siblings will (or will not) be willing to commit to care-giving (Neuharth and Stern 2002; Silverstein, Conroy and Gans 2008).

\section{An empirical example of the value of intergenerational moral capital}

In order to examine the potential of the moral capital model, we use data from the Longitudinal Study of Generations (LSOG) to test whether norms of filial responsibility of middle-aged children and their older mothers predict the amount of upstream support provided to mothers. We limited our analysis to older mothers to optimise the sample size and limit our focus to a single source of transmission. The LSOG began in 1971 with $35^{8}$ three-generation families living in Southern California ( see Bengtson and Schrader 1982 for sample details). Follow-up surveys were administered to original and newly eligible respondents in $198_{5}$, and then roughly every three years until 2005. All data have been collected by mail-back surveys. Response rates of eligible respondents have averaged 70 per cent over the life of the study. The sub-sample for this analysis comprised G2 mothers participating in the 1985 survey matched to their corresponding $\mathrm{G}_{3}$ children participating in the 2000 survey. The sample consisted of 379 mother-child dyads. In 20oo, mothers averaged 71.7 years of age and children averaged 47.6 years of age. Most of the responding children were daughters $(58.6 \%)$.

The provision of help and support was measured using four questions that asked adult children how often they provided the following four types of instrumental help and support to their mothers: (1) household chores, (2) transportation/shopping, (3) help when she/he is sick, and (4) assistance with personal care (e.g. help with bathing, dressing). Response categories were: not at all, once a year, several times a year, monthly, several times a month, weekly, several times a week, and daily. An additive scale was calculated potentially ranging from o (no support) to 28 (daily support) in the four areas.

Moral capital was operationalised by six items representing filial norms of eldercare responsibility using the following root question adapted from Heller (1976): Regardless of the sacrifices involved, how much responsibility should adult children with families of their own have:

1. To provide companionship or spend time with elderly parents who are in need?

2. To help with household chores and repairs and/or to provide transportation for elderly parents who are in need? 
3. To listen to the problems and concerns of elderly parents and to provide advice and guidance?

4. To provide for personal and health-care needs of the elderly parent (e.g. bathing, grooming, medication).

5. To provide financial support and/or assist in financial and legal affairs of elderly parents who are in need?

6. To provide housing for the elderly parents who are in need.

On each of the six items, respondents assigned responsibility on a fivepoint scale: none, minor, moderate, major and total. Responses were summed to form an additive scale ranging from zero (the least responsibility) to 24 (the most responsibility). The generalised nature of the question (as a norm rather than a self-expectation) tempers the bias of social desirability. In order to better specify the downward direction of transmission, filial responsibility as expressed by parents was taken from the 1985 survey and filial responsibility as expressed by children was taken from the 2000 survey. Other variables controlled included gender of children $(1$ =daughter, $\mathrm{o}=$ son $)$, and income, age and marital status $(1=$ married; $\mathrm{O}=$ unmarried) of mothers in 2000. Control variables were selected after a series of iterative models revealed that they explained the most variance in support.

We used Hierarchical Linear Modelling (Bryk and Raudenbush 1992) to estimate the joint influence of parents' and children's norms of filial responsibility on support provided to parents. This approach provides methodological and substantive advantages in our multi-sibling data by (a) appropriately taking into account the nested nature of the data structure, and (b) allowing child-level predictors to be represented as within-family differences (also known as centring by group-mean) such that each child's score on filial eldercare responsibility is treated as a deviation from other siblings in the family.

Estimated coefficients from the multi-level model are presented in Table 1. In terms of mother's characteristics, older, lower-income and unmarried (mostly widowed) mothers received more support from their children than did their younger, higher-income and married counterparts. In terms of children's characteristics, daughters provided more support to their mothers than did sons. Filial eldercare responsibility had no direct impact on support provision until it was considered together with the strength of mothers' filial norms $(p<0.07)$. That is, there was a synergistic effect of filial responsibility across generations. This conditional relationship is depicted graphically in Figure 1, showing that when mothers held relatively stronger filial norms of responsibility, their adult children were most likely to provide support when their sense of responsibility was strong 
T A B L E 1. Hierarchical linear model predicting social support from adult children to older mothers

\begin{tabular}{lrrrr}
\hline Fixed effect & Estimate & SE & Variance & $\chi^{2}(\mathrm{df})$ \\
\hline Intercept & $6.24^{* * *}$ & 0.26 & & \\
Mothers' characteristics ${ }^{1}$ : & $0.11^{*}$ & 0.05 & \\
$\quad$ Age & $-0.12^{*}$ & 0.06 & \\
$\quad$ Income & $1.49^{*}$ & 0.64 & & \\
$\quad$ Unmarried (versus married) & & & & \\
Children's characteristics ${ }^{2}$ : & $2.27^{*}$ & 0.92 & & \\
$\quad$ Daughter (versus son) & 0.05 & 0.11 & & \\
$\quad$ Filial eldercare norms & & & & \\
Cross-level interaction: & $0.06 \dagger$ & 0.03 & & \\
$\quad$ Filial eldercare norms of child by filial & & & & \\
$\quad$ eldercare norms of mother & & & $5.94^{* * *}$ & $229(92)$ \\
Random effect: & & & $0.36^{* *}$ & $132(94)$ \\
$\quad$ Intercept & & & 15.62 & - \\
$\quad$ Children's filial eldercare norms & & & \\
$\quad$ Level 1 & & &
\end{tabular}

Notes: 1. Variables at the mother-level are centred at the grand mean. 2. Variables at the childlevel are centred at the family mean. SE: standard error. df: degrees of freedom.

Significance levels: $\dagger p<0.10, * p<0.05, * * p<0.01, * * * p<0.001$.

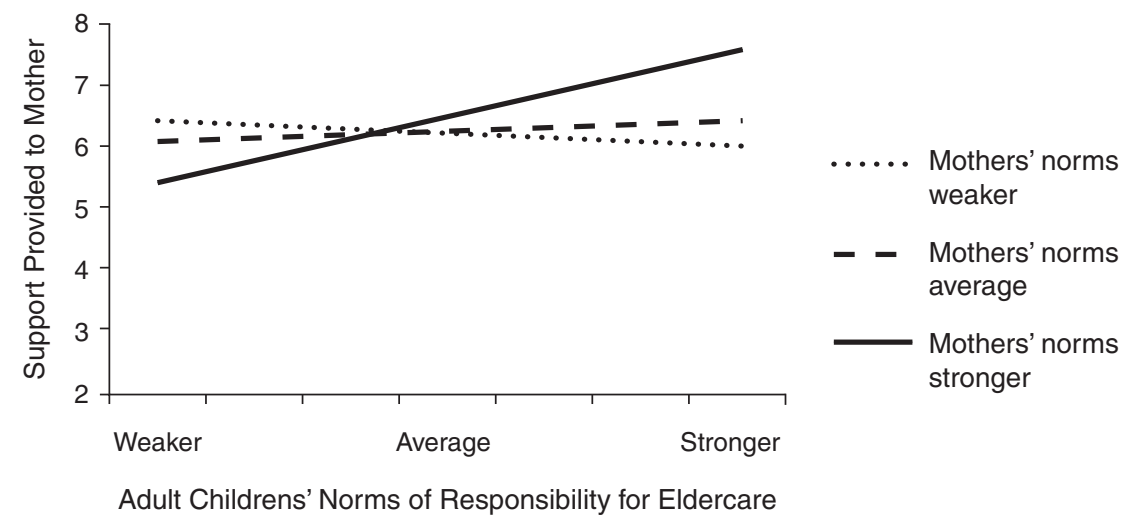

Figure 1. Social support provided by adult children to older mothers by filial eldercare norms of both generations.

relative to their siblings. Among children whose mothers had weaker eldercare norms, norms had little bearing on the volume of support they provided. Thus, a strong positive correspondence in the filial norms of adult children and their older mothers - possibly the result of intergenerational transmission processes earlier in life - elevated the supportive behaviour of children. 


\section{$125^{8}$ Merril Silverstein et al.}

\section{Discussion and conclusion}

In this paper, we have attempted to lay the groundwork for moral capital as a concept that helps explain why adult children provide support to their older parents. Evolutionary theory suggests a biological motive for why parents provide resources to their children (Hamilton 1964), but in the case of upward transfers to older parents, genetic reproduction is not at stake and, thus, we are faced with entertaining purely social explanations. Drawing on integrative mechanisms that focus on normative structures and transactional motives that focus on forms of enlightened self-interest, we developed the idea of pro-social norms as transmissible values across generations that have potential long-term benefit to the transmitter. By conceptualising the socialisation of children as a moral capital investment, we represent the family as moral economy within which parents inculcate their children to filial beliefs that redound positively to the parents in the form of future intergenerational support. Moral capital is an orientation to action that has value to parents that provides added certainty that children will be solicitous and possibly increases the likelihood that returns from other forms of investment in children will come to fruition.

Our discussion of moral capital has focused primarily on intra-familial relations without taking into consideration wider social structures. Where then does moral capital fit in relation to the welfare state that may substitute for family care? Public resources provided by the state are important considerations within a transactional approach to intergenerational transfers. The interdependence between the family and the generosity of welfare state regimes has been the topic of several multinational studies that generally find that the utility of intergenerational relations tends to be weaker in nations with more generous public services and benefits (Daatland and Lowenstein 2005; Hank 2007).

Related to these formulations are critical theories that trace how the expansion of free market global capitalism has increased family care-work through welfare state retrenchment and the privatisation of risk (Phillipson 2003). We argue that state support for its older citizens embodies a collective form of moral capital that, similar to its family-based counterpart, has compulsory elements (through taxation) and is reproduced across generations as a socially desirable end (manifest through stability in the political structure). Rather than conclude, as some cultural critics have, that there has been a general decline in the stock of moral capital in families over time, we argue that it is more likely that a portion of it has simply been transformed into its collective incarnation. Variation in filial norms across cultural groups presents a challenge to our framework as well. Strong preferences for family care have been noted in minority groups (Burr and Mutchler 1999) and it is 
probable that these preferences negatively correlate with access of such groups to state and/or private resources. In this sense, moral capital within families may be compensatory for disadvantage at the group or societal level.

We provided an empirical examination of norms of filial responsibility in two generations and showed evidence that support was maximised when both mothers and their children held strong norms of filial responsibility. Further, we found this interaction only when within-family sibling differences in norms were considered, not when the original value was used. This suggests that particular children are targeted for investment of moral capital and not all children within the same families are good bets. The mechanism of transmission may operate directly through training, discussion and modelling, or indirectly through third-party organisations over which parents have some control, such as religious and educational institutions that provide moral training of children. While we take correspondence in norms between mothers and children as evidence of transmission, alternative explanations may be at work. For instance, structural equivalence in occupational position across generations may provide an explanation for cross-generational correspondence that does not rest on socialisation.

We conclude by noting that the father of free-market economics, Adam Smith, fully recognised the limits of rational self-interest for explaining the motivations behind interpersonal transactions in families (Rosenberg 1990). In family relationships moral sentiments co-exist with rational concerns over resource expenditures and returns on investments. We have suggested in this paper that moral capital exists in the space between strategic investments (by parents) and simple altruism (of children), and as such represents two sides of the same intergenerational coin. We suggest that moral capital may be a useful unifying concept that bridges disciplinary and theoretical divides in the study of intergenerational transfers to the elderly by helping resolve the paradox of how self-interest and selflessness can co-exist within families.

\section{References}

Altonji, J., Hayashi, F. and Kotlikoff, L. 1992. Is the extended family altruistically linked? Direct tests using micro data. American Economic Review, 82, 5, $1177-98$.

Andreoni, J. 1990. Impure altruism and donations to public goods: a theory of warmglow giving? Economic Journal, Royal Economic Society, 100, 401, 464-77.

Antonucci, T. 1990. Social supports and social relationships. In Binstock, R. H. and George, L. K. (eds), Handbook of Aging and the Social Sciences. Third edition, Academic Press, New York, 205-26.

Attias-Donfut, C. 2000. Cultural and economic transfers between generations: one aspect of age integration. The Gerontologist, 4o, 3, 270-2.

Becker, G. S. 1991. A Treatise on the Family. Enlarged edition, Harvard University Press, Cambridge, Massachusetts. 
Becker, G. 1993. Nobel lecture: The economic way of looking at behavior. Journal of Political Economy, 101, 3, 385-409.

Bengtson, V. L., Biblarz, T.J. and Roberts, R. E. L. 2002. How Families Still Matter: A Longitudinal Study of Youth in Two Generations. Cambridge University Press, New York.

Bengtson, V. L. and Schrader, S. S. 1982. Parent-child relations. In Mangen, D. J. and Peterson, W. (eds), Handbook of Research Instruments in Social Gerontology. University of Minneapolis Press, Minneapolis, Minnesota, $115^{-85}$.

Bernheim, D., Shleifer, A. and Summers, L. 1985. The strategic bequest motive. Journal of Political Economy, 33, 4, 1045-76.

Bernheim, D. and Stark, O. 1988. Altruism within the family reconsidered: do nice guys finish last? American Economic Review, 78, 5, 1034-45.

Bryk, A. S. and Raudenbush, S. W. 1992. Hierarchical Linear Models: Applications and Data Analysis Methods. Sage Publications, Thousand Oaks, California.

Burgess, E. W. 1960. Ageing in Western Societies. University of Chicago Press, Chicago.

Burr, J.A. and Mutchler, J.E. 1999. Race and ethnic variation in norms of filial responsibility among older persons. Journal of Marriage and the Family, 61, 3, $674-87$.

Caputo, R. K. 2002. Rational actors versus rational agents. Journal of Family and Economic Issues, 23, 1, 27-50.

Cicirelli, V. G. 1993. Attachment and obligation as daughters' motives for caregiving behavior and subsequent effect on subjective burden. Psychology and Aging, 8, 2, $144^{-} 55^{\text {. }}$

Clarke, E., Preston, M., Raksin, J. and Bengtson, V. L. 1999. Types of conflicts and tensions between older parents and adult children. Gerontologist, 39, 3, 261-70.

Coleman, J. S. 1988. Social capital in the creation of human capital. American Journal of Sociology, 94, supplement, S95-120.

Cox, D. and Rank, M. R. 1992. Inter-vivos transfers and intergenerational exchange. The Review of Economics and Statistics, 74, 2, 305-14.

Cox, D. and Stark, O. 1992. Intergenerational transfers and the demonstration effect. Working paper, Harvard University Press, Cambridge, Massachusetts.

Daatland, S. O. and Lowenstein, A. 2005. Intergenerational solidarity and the familywelfare state balance. European Journal of Aging, 2, 3, $174-82$.

Finch, J. and Mason, J. 1991. Obligations of kinship in contemporary Britain: is there normative agreement? The British Journal of Sociology, 42, 3, 345 -67 .

Furstenberg, F. F. and Kaplan, S. B. 2004. Social capital and the family. In Scott, J., Treas, J. and Richards, M. (eds), The Blackwell Companion to the Sociology of Families. Blackwell Publishing, Oxford, $218-32$.

Glass, J., Bengtson, V.L. and Dunham, C. 1986. Attitude similarity in threegeneration families: socialization, status inheritance, or reciprocal influence? American Sociological Review, 51, 5, 685-98.

Goode, W.J. 1963. World Revolution and Family Patterns. Free Press, New York.

Hamilton, W. D. 1964. The genetical evolution of social behaviour. Journal of Theoretical Biology, 7, 1, 17-52.

Hank, K. 2007. Proximity and contacts between older parents and their children: a European comparison. Journal of Marriage and Family, 69, 1, 157-73.

Heider, F. 1958. The Psychology of Interpersonal Relations. Wiley, New York.

Heller, P. L. 1976. Familism scale: revalidation and revision. Journal of Marriage and the Family, 38, 3, 423-9.

Henretta, J. C., Hill, M. S., Li, W., Soldo, B. J. and Wolf, D. A. 1997. Selection of children to provide care: the effect of earlier parental transfers. Journals of Gerontology: Psychological and Social Sciences, 52 B, special issue, $110-19$. 
Homans, G. C. 1950. The Human Group. Harcourt, Brace and World, New York.

Ikkink, K. K., Van Tilburg, T. and Knipscheer, K. 1999. Perceived instrumental support exchanges in relationships between elderly parents and their adult children: normative and structural explanations. Journal of Marriage and the Family, 61, $4,831-44$.

Jellal, M. and Wolff, F. C. 2002. Cultural evolutionary altruism: theory and evidence. European Journal of Political Economy, 18, 241-62.

Kohlberg, L. 1981. The Philosophy of Moral Development. Harper \& Row Publishers, New York.

Lennartsson, C., Silverstein, M. and Fritzell, J. 2010. Time-for-money exchanges between older and younger generations in Swedish families. Journal of Family Issues, 31, 2, 189-210.

Leuscher, K. and Pillemer, K. A. 1998. Intergenerational ambivalence: a new approach to the study of parent-child relations in later life. Journal of Marriage and Family, 6o, 2, 413-25.

Litwak, E. 1960. Geographic mobility and extended family cohesion. American Sociological Review, 25, 3, 385-94.

Litwak, E. 1985. Helping the Elderly: The Complementary Roles of Informal Networks and Formal Systems. Guilford Press, New York.

Logan, J. and Spitze, G. 1995. Self-interest and altruism in intergenerational relations. Demography, 32, 3, 353-64.

Lowenstein, A., Katz, R. and Gur-Yaish, N. 2007. Reciprocity in parent-child exchange and life satisfaction among the elderly in cross-national perspective. Journal of Social Issues, $\mathbf{6}_{3}, 4,86_{5}-83$.

Mauss, M. 1923/1967. The Gift: Forms and Functions of Exchange in Archaic Societies. Translator Ian Cunnison, Norton, New York.

McGarry, K. and Schoeni, R. 1997. Transfer behavior within the family: results from the Asset and Health Dynamics Study. Journals of Gerontology, 52 B, special issue, $82-92$.

Neuharth, T. J. and Stern, S. 2002. Shared caregiving responsibilities of adult siblings with elderly parents. Journal of Human Resources, 37, 3, 441-78.

Ogburn, W. F. 1933. The family and its functions. In Report of the President's Research Committee on Social Trends. Volume: 1. McGraw-Hill, New York, 661-708.

Parrott, T. M. and Bengtson, V.L. 1999. The effects of earlier intergenerational affection, normative expectations, and family conflict on contemporary exchanges of help and support. Research on Aging, 21, 1, 73-105.

Parsons, T. and Bales, R. F. 1955. Family, Socialization and Interaction Process. The Free Press, Glencoe, Illinois.

Peek, M. K., Coward, R. T., Peek, C. W. and Lee, G. R. 1998. Are expectations for care related to the receipt of care? An analysis of parent care among disabled elders. Journals of Gerontology: Social Sciences, 53B, 3, S1 27-36.

Phillipson, C. 2003. Globalization and the reconstruction of old age: new challenges for critical gerontology. In Biggs, S., Lowenstein, A. and Hendricks, J. (eds), The Need for Theory: Critical Approaches to Social Gerontology. Baywood, New York, $163-79$.

Ribar, D. C. and Wilhelm, M. O. 20o6. Exchange, role modeling and the intergenerational transmission of elder support attitudes: evidence from three generations of Mexican-Americans. The Journal of Socio-Economics, 35, 3, 514-31.

Roberts, R. E. L., Richards, L. N. and Bengtson, V. L. 1991. Intergenerational solidarity in families: untangling the ties that bind. Marriage and Family Review, 16, $1 / 2,11-46$. 
Rosenberg, N. 1990. Adam Smith and the stock of moral capital. History of Political Economy, 22, 1, 1-18.

Rosenmayr, L. 1968. Family relations of the elderly. Journal of Marriage and the Family, 3o, $4,672-8$ o.

Rossi, A. S. and Rossi, P. H. 1990. Of Human Bonding: Parent-Children Relationship Across the Life Course. Aldine de Gruyter, New York.

Shanas, E. and Sussman, M. 1977. Family, Bureaucracy, and the Elderly. Duke University Press, Durham, North Carolina.

Silverstein, M., Bengtson, V. L. and Lawton, L. 1997. Intergenerational solidarity and the structure of adult child-parent relationships in American families. American Journal of Sociology, 103, 2, 429-60.

Silverstein, M. and Conroy, S. J. 2009. Intergenerational transmission of moral capital across the family life course. In Schoenpflug, U. (ed.), Cultural Transmission. Cambridge University Press, New York, 31 7-37.

Silverstein, M., Conroy, S.J. and Gans, D. 2008. Commitment to caring: filial responsibility and the allocation of support by adult children to older mothers. In Szinovacz, M. E. and Davey, A. (eds), Caregiving Contexts: Cultural, Familial and Societal Implications. Springer Publishing Company, New York, 71-92.

Silverstein, M., Conroy, S.J., Wang, H., Giarrusso, R. and Bengtson, V. L. 2002. Reciprocity in parent-child relations over the adult life course. Journals of Gerontology: Social Sciences, 57, 1, $\mathrm{S}_{3}-\mathbf{1} 3$.

Sloan, F., Zhang, H. and Wang, J. 2002. Upstream intergenerational transfers. Southern Economic Journal, 69, 2, 363-80.

Smith, A. 1790. The Theory of Moral Sentiments. Sixth edition, Library of Economics and Liberty. Available online at http://www.econlib.org/library/Smith/smMS 1.html [Accessed 25 March 2010].

Stein, C. H., Wemmerus, V. A., Ward, M., Gaines, M. E., Freeberg, A. L. and Jewell, T. 1998. 'Because they're my parents': an intergenerational study of felt obligation and parental caregiving. Journal of Marriage and the Family, 6o, 3, 61 1-22.

Taris, T.W. and Semin, G. R. 1997. Passing on the faith: how mother-child communication influences transmission of moral values. Journal of Moral Education, 26, 2, 211 1-2 1.

Whitbeck, L. B., Simons, R. L. and Conger, R. D. 1991. The effects of early family relationships on contemporary relationships and assistance patterns between adult children and their parents. Journals of Gerontology: Social Sciences, 46, 6, S3O1-37.

Willson, A. E., Shuey, K. M. and Elder, G. H. 2003. Ambivalence in the relationship of adult to aging parents and in-laws. Journal of Marriage and Family, $\mathbf{6}_{5}, 4$, $1055^{-72 .}$

Wirth, L. 1938. Urbanism as a way of life. American Journal of Sociology, 44, 1, 1-24.

\section{Address for correspondence:}

Merril Silverstein, Davis School of Gerontology,

University of Southern California,

Los Angeles, CA goo89, USA

E-mail: merrils@usc.edu 